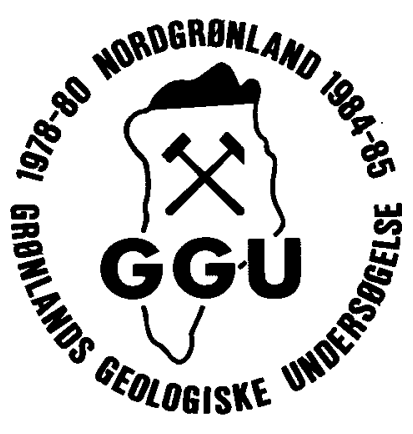

\title{
Aspects of Franklinian shelf, slope and trough evolution and stratigraphy in North Greenland
}

\author{
Finn Surlyk and J. R. Ineson
}

The Early Palaeozoic Franklinian basin of North Greenland was initiated in early Cambrian times with the onset of siliciclastic and mixed carbonate shelf deposition on a substratum of Proterozoic sediments and Precambrian crystalline basement. The basin rapidly differentiated into shelf, slope, and trough environments. The boundary between these major depositional regimes follows major roughly east-west trending lineaments.

The inner-outer shelf transition fluctuated widely in position and was controlled by the interplay between sea-level changes and periodic northwards downwarping.

In Ordovician-Silurian times the margin of the carbonate platform migrated northwards to coincide with the shelf-slope break and had a steep scarp configuration with an abrupt transition to the shales and turbidites of the deep-water basin. In this paper we pay special attention to the initial basin sequence (Skagen Group), the collapsed and broken platform carbonates of the Lower Cambrian Portfjeld Formation, the Middle - Late Cambrian inner-outer shelf transition and to the nature of the Silurian platform margin scarp.

F. S., Grønlands Geologiske Undersøgelse, Øster Voldgade 10, DK-1350 København K, Denmark.

J. R. I., British Antarctic Survey, High Cross, Madingley Road, Cambridge CB3 OET, England. Present address: University of London, Goldsmiths' College, New Cross, London SE14 6NW, U.K.

It has been known for a long time that the Early Palaeozoic basin of North Greenland contains marine deposits of both shallow and deep-water origin. General reviews of this earlier work have been given by e.g. Dawes (1976). Surlyk et al. (1980) presented a general hypothesis for the differentiation of the sequence into shelf, slope and trough environments providing an integrated scheme of correlation between the environments. The boundaries between these depositional regimes were described within the framework of an extensional basin governed by major lineaments representing deep-seated down-to-basin faults or flexures (Hurst \& Surlyk, 1980). Subsequent regional studies by the writers and others have confirmed the correlations and refined the model of basin development (e.g. Friderichsen \& Bengaard, 1985; Higgins \& Soper, 1985; Hurst \& Surlyk, 1982, 1983, 1984; Hurst et al., 1983; Ineson, 1985; Ineson \& Peel, 1987; Larsen \& Escher, 1985; Surlyk \& Hurst, 1984). 
In the 1985 field season it was our aim to unravel the precise nature of the mid and late Cambrian shelf-slope-trough transition which appeared to represent a complicated phase in the evolution of the basin (Hurst \& Surlyk, 1983; Ineson, 1985). Furthermore we studied or re-examined localities critical for the understanding of the inner-to-outer shelf transition, the shelf-slope break, and the stages in evolution of the deep-water trough described by Surlyk et al. (1980) and Surlyk \& Hurst $(1983,1984)$. Finally the four-fold subdivision presented for the upper Lower Cambrian - Lower Silurian outer shelf to slope deposits of the coastal region of central and western North Greenland by Higgins \& Soper (1985) was examined. It now seems to be possible to construct an integrated shelf-slope-trough stratigraphic scheme as a result of the cooperation with the workers in the carbonate platform region to the south and in the now folded, deep-water trough sequence to the north.

In the present paper we place the main emphasis on the hitherto little known initial shelf sequence, on the collapsed Lower Cambrian carbonate platform sequence, on the Middle Late Cambrian transition from the carbonate platform of the inner shelf to dark siliciclastic and carbonate mudstones of the outer shelf, and on the nature of the early Silurian platform margin scarp.

\section{Initiation of the Early Palaeozoic basin (Skagen Group)}

The oldest sediments of the Early Palaeozoic basin are exposed in the core of some of the large anticlinal structures which extend from the northern part of Wulff Land over Stephenson $\emptyset$, northern parts of Nares Land, Freuchen Land, and Lauge Koch Land to the east coast of J. P. Koch Fjord (fig. 1). The thickly developed sequence underlies the Lower Cambrian Portfjeld Formation, which along the southern margin of the basin rests directly on Late Proterozoic sediments. The pre-Portfjeld Formation sediments thus wedge out over a few tens of kilometres from the northern outcrop belt to the southern exposure of the Portfjeld Formation.

The pre-Portfjeld Formation beds occupy a stratigraphic position similar to that of the Skagen Group in the deep-water sequence of Peary Land. This group underlies the basinal carbonates of the Paradisfjeld Group which forms the deep-water equivalent to the shallow marine carbonate platform deposits of the Portfjeld Formation (Surlyk et al., 1980).

The Skagen Group was erected by Friderichsen et al. (1982) for an intensely deformed thick sequence of sandstone and shale underlying the Paradisfjeld Group. The Skagen Group, however, has not received any sedimentological study, and it is therefore not clear if it represents the same type of shelf deposits as the pre-Portfjeld beds of the Wulff Land anticline or if it is of deeper water origin. As the main rock types are similar in the two units (Higgins \& Soper, 1985) the pre-Portfjeld Formation beds are tentatively included in the Skagen Group in the present paper.

The Skagen Group of the anticline in northern Wulff Land is between 500 and $600 \mathrm{~m}$ thick, but the base of the unit is not exposed (fig. 2). The sediments are of marine shelf origin and a number of characteristic siliciclastic, carbonate, and mixed facies occur. The five major facies associations recognised in Wulff Land occur as discrete units that may be classified as formations in a formal lithostratigraphic scheme. It is not yet fully clear, however, how far the units can be traced laterally in the northern outcrop belt.

The oldest unit (formation 1) is thickly developed in northern Wulff Land where it consists of about $200 \mathrm{~m}$ of dark heterolithic siltstone and fine sandstone showing rhythmic lami- 


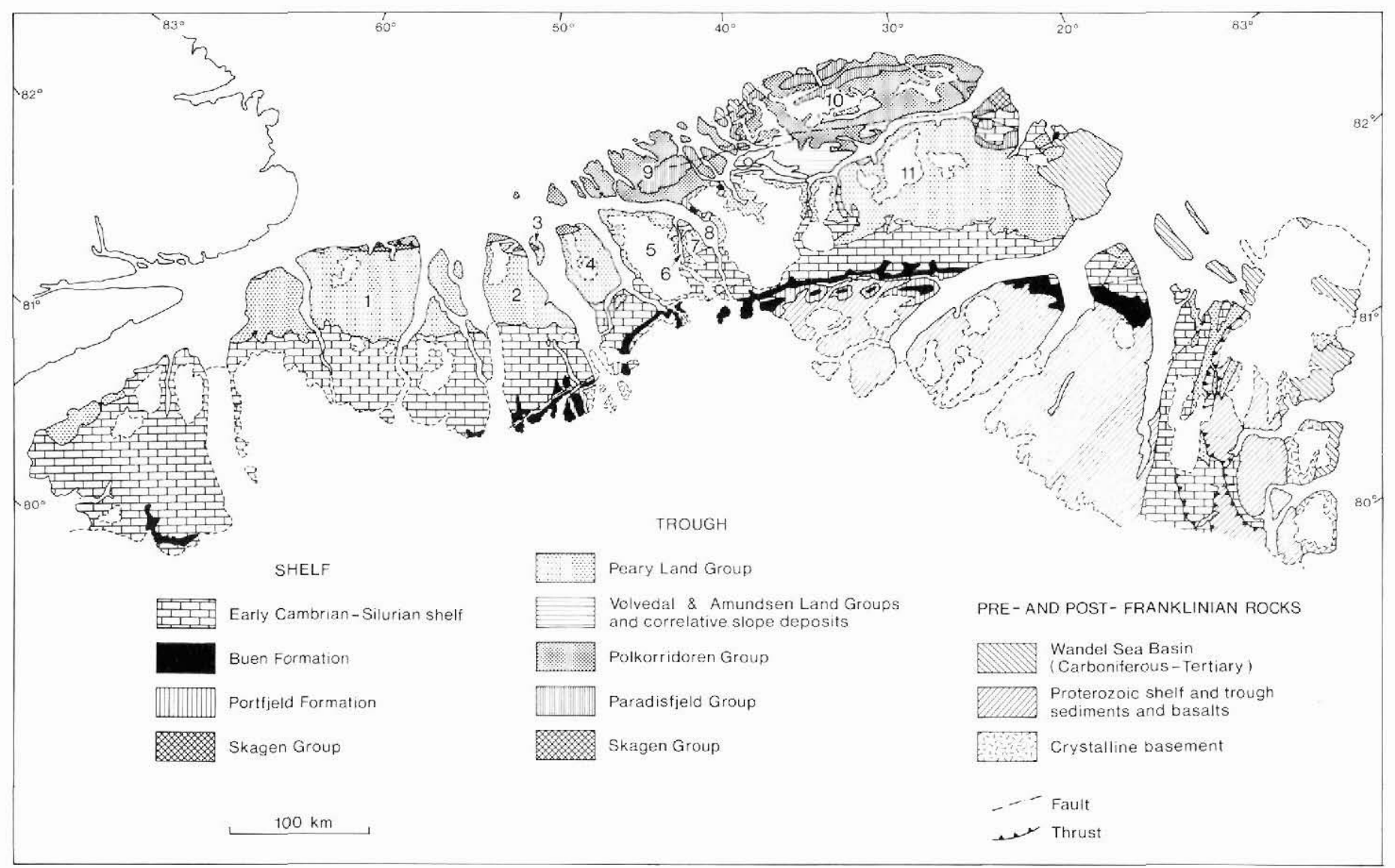

Fig. 1. Schematic geological map showing the position of land areas and localities mentioned in the text. 1: Hall Land, 2: Wulff Land, 3: Stephenson $\varnothing, 4$ : Nares Land, 5: Freuchen Land, 6: Navarana Fjord, 7: Lauge Koch Land, 8: J. P. Koch Fjord, 9: Nansen Land, 10: Johannes V. Jensen Land which is the northern part of 11: Peary Land. 


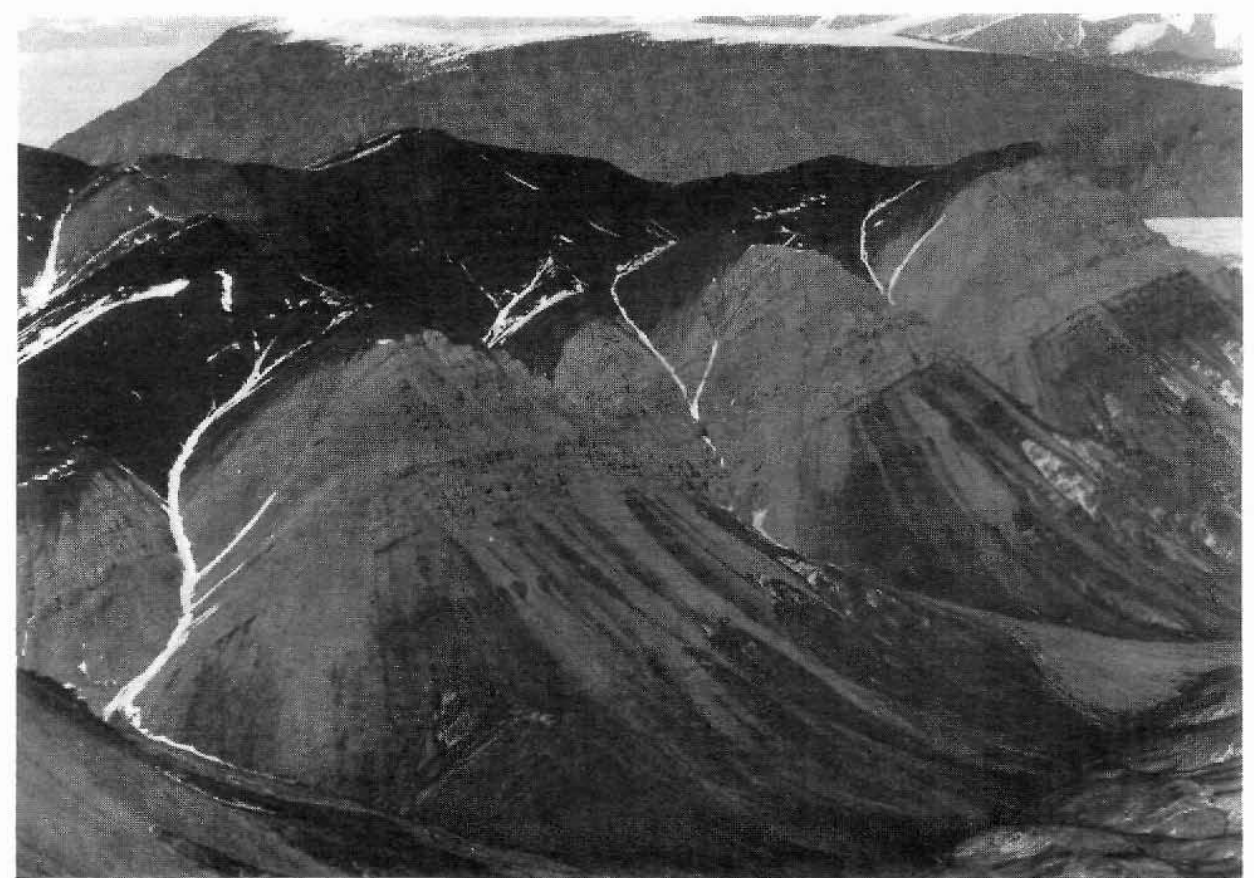

Fig. 2. Northern limb of large anticline in northern Wulff Land. The dark mudstones, sandstones and dolomites of the Skagen Group are exposed in the valley. They are overlain by $340 \mathrm{~m}$ of crag-forming light dolomites of the Portfjeld Formation which itself is overlain by light sandstones (forming the top of the crag) and dark mudstones of the Buen Formation.

nation, and lenticular, wavy and flaser bedding. Cross-lamination indicates palaeocurrents towards the southwest. The unit shows a crude coarsening-upwards tendency marked by the incoming of distal, hummocky cross-stratified pebbly quartz sandstones. Some of the sandstones contain abundant ooids. The generally fine-grained, dark coloured sediments of formation 1 were laid down in a quiet offshore shelf in depths mainly below storm-wave base. Transport of sand into this environment took place during major storm events when the hummocky cross-stratification was formed.

The coarsening-upwards trend culminates with the abrupt appearance of thick, pebbly, brown-weathering quartzitic sandstones (formation 2). They are interbedded with oolitic sandy dolomites or dolomitic pebbly sandstones with intraclasts and ooids, and heterolithic sequences. The coarse grained beds display hummocky cross-stratification, parallel bedding, very large-scale trough cross-bedding and, less commonly, current- and wave-ripple crosslamination. Palaeocurrents are unimodal towards the north-northwest. The incoming of very coarse textured and structured facies is taken to reflect a marked progradational phase. The environment can be characterised as a storm dominated inner shelf with depths between fairweather and storm-wave base. The existence of adjacent contemporaneous shallow marine carbonate shoals is indicated by the ubiquitous occurrence of dolomite beds, ooids, oolitic and other carbonate intraclasts. Formation 2 represents the first differentiation of the shelf into a carbonate platform and a mainly siliciclastic storm influenced shelf. The localisation of 
the transition between these two environments is not known. It is very likely that the formation is a lateral facies equivalent to the deepest part of the Portfjeld Formation platform carbonates. The marked northwards increase in the thickness of the latter formation (see below) suggests that a northern fringe of platform carbonates was formed already at the time of deposition of formation 2. Formation 2 seems to have an overall lenticular shape and it occurs higher in the Skagen Group sequence in the Navarana Fjord area than in Wulff Land.

In northern Wulff Land formation 2 is followed by up to $120 \mathrm{~m}$ of heterolithic siltstone and fine sandstone, laminated siltstone, and black sandy dolomite which constitute formation 3 . This clearly indicates a shift to more quiet depositional conditions than formation 2 . It is not known, however, if the general facies change reflects a deepening or transgressive event or just a lateral migration of the coarse textured shoals represented by formation 2 . The wedgeshaped nature and/or apparent time-transgressive nature of formation 2 tends to support the second interpretation.

In northern Wulff Land the fine-grained siliciclastic deposits of formation 3 give way to dark crag-forming dolomites of formation 4. This highly characteristic facies consists of dark-grey, massive dolomite with abundant irregular cracks, veins, and vugs filled with white dolomite spar (fig. 3B). Small platy intraclasts occur abundantly in this facies which forms units up to $35 \mathrm{~m}$ thick. The vuggy structures are similar to 'Zebra stromatactis' (James, 1983, figs 132, 133) and may reflect early diagenesis in a very shallow marine, perhaps intertidal environment. The dark grey veined dolomites pass upwards into light grey laminated siltstone with dolomite interbeds suggesting deposition under low-energy conditions. Formation 4 is $50-70 \mathrm{~m}$ thick. It is overlain by dark banded dolomites of formation 5 (fig. 3A). This formation begins with about $65 \mathrm{~m}$ dark-grey, hummocky cross-stratified intraclast dolomites (fig. 3A). Some beds display the same type of cracks and veins filled with white dolomitic spar as seen in formation 4 . This facies was probably deposited adjacent to (south of?) a stable carbonate platform represented by the basal Portfjeld Formation at depths above storm-wave base. The carbonate material was swept away from the platform during strong storm.

\section{The Portfjeld Formation}

This formation was studied in northern Wulff Land, where a complete section was measured, and on the east coast of Navarana Fjord. The thickness of the formation in Wulff Land is $340 \mathrm{~m}$. It is composed almost entirely of light coloured dolomitised ooid-intraclast grainstones, locally showing hummocky cross-stratification or trough cross-bedding, parallel and cross-lamination. Intervals with domal or columnar club-shaped stromatolites and oncolitic grainstones occur scattered through the sequence.

Throughout North Greenland the formation thickens appreciably towards the north from 200-280 $\mathrm{m}$ in southern Peary Land (O'Connor, 1979) to 400-700 $\mathrm{m}$ in northeast Peary Land, and from $260 \mathrm{~m}$ in Navarana Fjord to an estimated $500 \mathrm{~m}$ east of J. P. Koch Fjord in northwesternmost Peary Land (Higgins \& Soper, 1985). The thick succession of mainly highenergy shallow marine carbonates in the northern exposures clearly represents the outer rim of the platform with maximum subsidence and vertical accretion. The thickness difference and the occurrence of mixed carbonate-siliciclastic deposits in the upper part of the underlying Skagen Group suggest that deposition of Portfjeld Formation carbonates was initiated in the outer shelf while the inner shelf still received terrigenous sand and mud. The bound- 

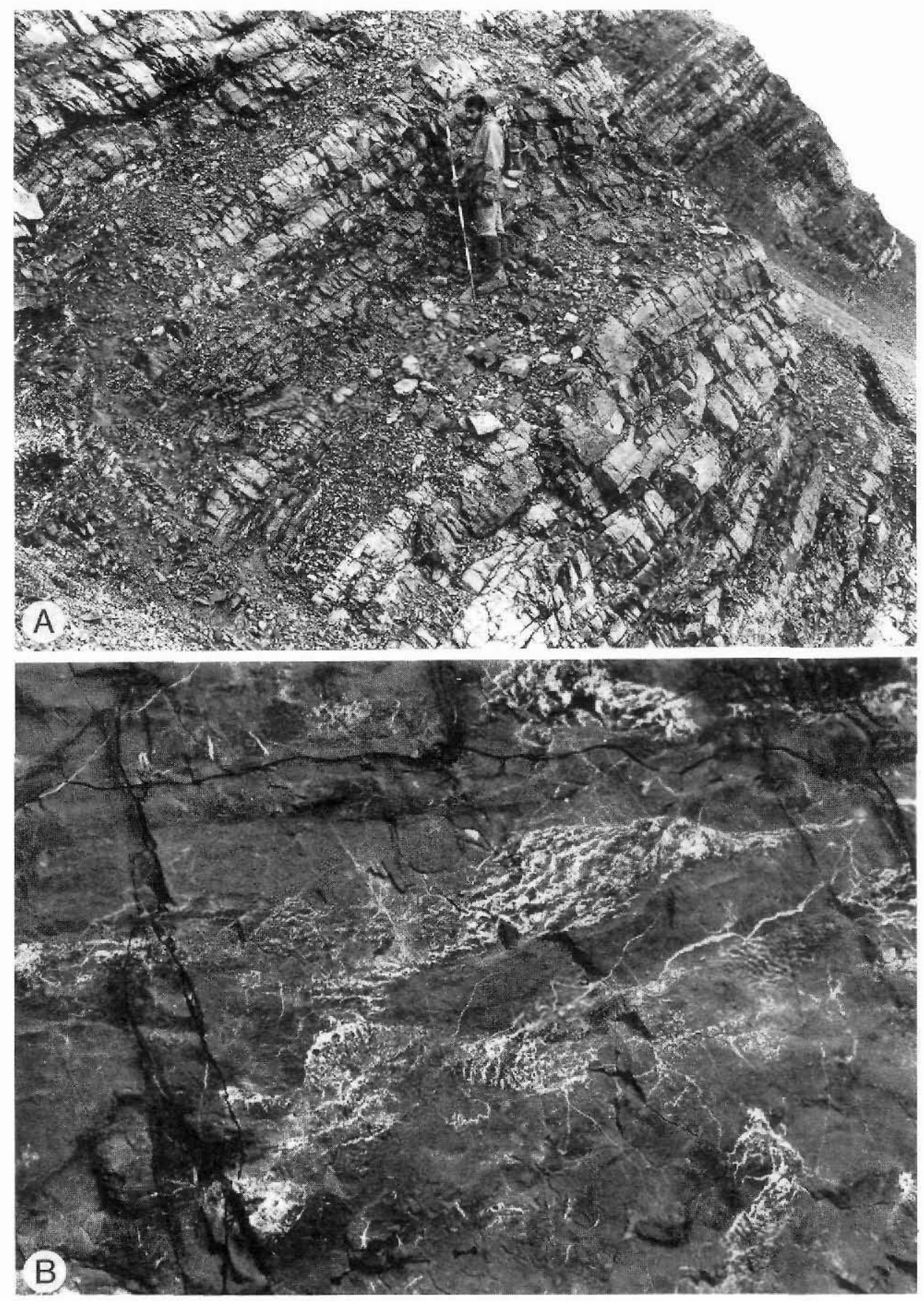

Fig. 3. A. Close-up of the hummocky cross-stratified dolomites which form the top part (formation 5) of the Skagen Group (fig. 2). B. 'Zebra stromatactis' in dark-grey massive dolomites of formation 4 in the Skagen Group. Same locality as fig. 2. 
ary between the Portfjeld Formation and the deep-water basinal carbonates of the Paradisfjeld Group was probably abrupt in the form of a steep scarp (Surlyk \& Hurst, 1983, 1984). Huge olistoliths derived from the Portfjeld Formation occur in southern Nansen Land in the lower part of the turbiditic Polkorridoren Group which overlies the Paradisfjeld Group (Friderichsen \& Bengaard, 1985). This suggests that the Portfjeld scarp persisted or was revived by later faulting so that parts of it were still exposed in Buen-Polkorridoren times (Soper \& Higgins, submitted) or that Portfjeld Formation carbonates were exposed in deeply cut submarine canyons (Friderichsen \& Bengaard, 1985).

\section{Collapsed and broken Portfjeld Formation}

An important tectonic event took place along the southern basin margin around the head of Victoria Fjord following deposition of the Portfjeld Formation. This is reflected by the occurrence in southern Wulff Land and adjacent areas of a remarkable mega-breccia essentially formed by collapse, breakage, and mass transport of the entire Portfjeld Formation together with material from some of the underlying units (fig. 4). The sequence was briefly mentioned by Hurst \& Peel (1979) and Peel \& Wright (1985) and was mapped by H. F. Jepsen in 1984. The redeposited Portfjeld Formation is $85-270 \mathrm{~m}$ thick. It rests on an irregular topography of crystalline basement or thin remnants of the Upper Proterozoic Morænesø Formation and is itself overlain by undisturbed sandstone and mudstone of the Buen Formation. It consists mainly of blocks and large slabs of Portfjeld Formation together with large clasts of quartzite, gneissic basement rocks, red siltstone, and diamictites of the Morænes $\emptyset$ Formation. The larger slabs are more than $100 \mathrm{~m}$ long and may be tens of metres thick. They are mainly subhorizontally orientated. They show, however, all degrees of deformation from weak bending and doming to strong folding, faulting, and shearing. The slabs may have sharp boundaries or they may pass into gradually more deformed strata and eventually into disorganised conglomerates. The unit thus consists of two main components, breccias and slabs or blocks of dolomite and other rock types and a 'matrix' of disorganised conglomerate.

The conglomerate clasts are very angular, very poorly sorted and consist of dolomite, chertified dolomite, greenish and black chert, quartzite, gneiss, and other basement rocks. The dolomite clasts display a great variety of structures and textures known from the Portfjeld Formation. Particularly characteristic are cream coloured oolitic and pisolitic dolomites. The conglomerate matrix consists of carbonate with abundant quartz grains which commonly are very well rounded.

The matrix-rich conglomerates show all types of relations with the large, more or less deformed dolomite slabs or rafts. They may thus pass laterally into internally undeformed slabs with a gradual transition. Intrusive relations have also been observed, as have intrusion-like features which on close inspection are seen to represent breakage and thorough mixing of localised areas within the larger slabs. Some dolomite rafts show highly sutured, amoeboid margins indicating a semi-plastic state at the time of incorporation.

In spite of the ubiquitous occurrence of folded slabs, directional features are not immediately obvious in the field. The orientation in southern Wulff Land of about 20 large tilted or bent slabs shows a tendency to dominance by NNE-NNW-NW strike directions mainly with south-westerly or westerly dipping flanks preserved. About 10 measured fold axes strike be- 


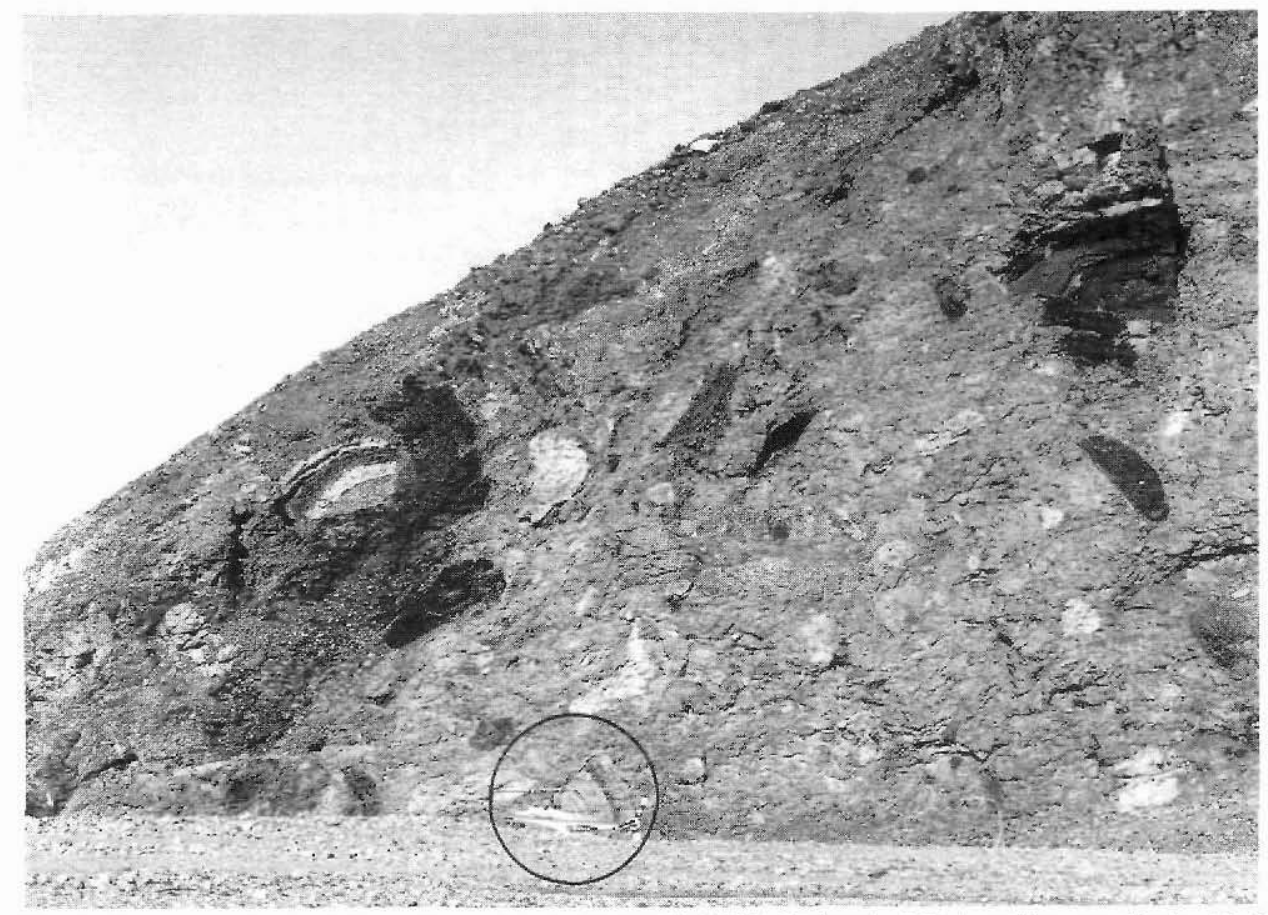

Fig. 4. Mega-breccia consisting of huge blocks of Portfjeld lithologies $(>90 \%)$, red-brown thin-bedded dolomite of the Morænesø Formation, and crystalline basement. South of Apollo Sø, southern Wulff Land. Note helicopter for scale (encircled). Photo by H. F. Jepsen.

tween east and northeast and the folds are overturned to the north to northwest. These data suggest a general northwards transport direction varying within the NW-N-NE quadrant.

It is envisaged that violent earthquake activity associated with faults along the southern hinge line of the Franklinian basin shattered and mobilised the partly lithified Morænes $\emptyset$ and Portfjeld Formations. It is possible that initial brecciation in the southernmost platform region was caused by karstification or by solution of evaporites. Rock flour from the broken and fragmented parts of the two formations became lubricated with water and mixed with unconsolidated carbonate sediment, forming viscous slurries, and down-slope movement was initiated on the hard, rounded, smooth basement.

A zone of large-scale deformation with upright folds located by H. F. Jepsen in 1984 in the land area south of Nares Land may indicate banking up of the mega-debrite against unbroken Portfjeld Formation. Some of the brecciated material may have flowed across the carbonate platform to be deposited in the trough. Such deposits could be represented by the olistoliths of Portfjeld carbonates which occur in the basal turbidites and mudstones of the Polkorridoren Group (Friderichsen \& Bengaard, 1985). 


\section{Cambrian shelf sedimentation}

Shelf sedimentation during the latter part of the Cambrian can be regarded in terms of two depositional systems, a shallow-water carbonate platform to the south represented by the Ryder Gletscher Group and a mixed siliciclastic-carbonate outer shelf represented by the Brønlund Fjord and Tavsens Iskappe Groups. A detailed example of the relationships between these systems in southwest Freuchen Land is given by Ineson \& Peel (1987). West of Freuchen Land, outcrops are dominated by facies of the stable carbonate platform (Peel \& Wright, 1985; Ineson \& Peel, 1987), and outer shelf rocks are restricted to northernmost Nares Land, Wulff Land and Nyeboe Land (Higgins \& Soper, 1985); the transition between these facies is covered by younger strata in this area. In Peary Land, Lauge Koch Land and southern Freuchen Land, however, the Brønlund Fjord and Tavsens Iskappe Groups record the progressive northward progradation of inner shelf deposits over outer shelf facies from the late Early Cambrian to the earliest Ordovician (Ineson \& Peel, 1980; Ineson, 1985). The rate and style of progradation was dependent largely on sea-level fluctuations, and a reciprocal pattern of sedimentation is evident - pulses of carbonate sedimentation and progradation of carbonate platform and slope deposits alternated with siliclastic incursions into both inner and outer shelf environments. The overall regressive pattern of sedimentation culminated in progressive subaerial exposure of the eastern portion of the North Greenland shelf (Ineson, 1985), probably in response to uplift along the eastern (Caledonian) margin of North Greenland (Hurst \& Surlyk, 1983; Surlyk \& Hurst, 1984).

Progradation of inner shelf over outer shelf facies is commonly associated with spectacular clinoform bedding, both within carbonate platform margin deposits (see Ineson, 1985; Ineson \& Peel, 1987) and in the mixed carbonate-clastic deposits of the Perssuaq Gletscher Formation. The example described here is from the latter formation at the eastern margin of Freuchen Land, on the west side of the glacier flowing into Navarana Fjord (fig. 1).

The Middle(?) Cambrian - lowermost Ordovician clastic-dominated deposits of the Perssuaq Gletscher Formation in this area immediately underlie the unconformity with the upper Lower - lower Middle Ordovician Wandel Valley Formation and clearly represent the final regiessive pulse prior to exposure of this part of the North Greenland shelf (fig. 5). This clastic influx can probably be correlated with the shallow-marine sandstones of the Permin Land Formation and Røhling Land Member farther west (Bryant \& Smith, 1985; Sønderholm \& Due, 1985) and the Vølvedal Group turbidites in the deep-water trough to the north (Friderichsen et al., 1982; Surlyk \& Hurst, 1984; Surlyk et al., unpublished).

The section in eastern Freuchen Land consists of an alternation of clastic and carbonate units showing northward depositional dips ranging from $17^{\circ}$ to more than $30^{\circ}$ (fig. 7). Carbonate units (2-10 m thick) typically comprise intensely bioturbated, mottled pale dolomites, but they locally show irregular cryptalgal lamination and low-relief thrombolitic algal mounds with a poorly-preserved columnar internal structure. Siliciclastic units are up to 40 $\mathrm{m}$ thick and are composed mainly of fine-grained, well-rounded, well-sorted quartz sand. Four main facies are recognised. Thick-bedded (5-15 m) matrix-supported conglomerates consist of pebbles and cobbles of intraformational sandstone dispersed in a well-sorted sand matrix (fig. 8; $110 \mathrm{~m}$ and $260 \mathrm{~m}$ in fig. 7). Weak normal grading and imbrication are locally developed and the upper portion may show parallel or cross-stratification $(120 \mathrm{~m}$ and $270 \mathrm{~m}$ in fig. 7); these beds represent high-density, sediment-gravity flows. Trough cross-bedded sandstones indicate northward palaeocurrents and grade down the depositional slope, into 


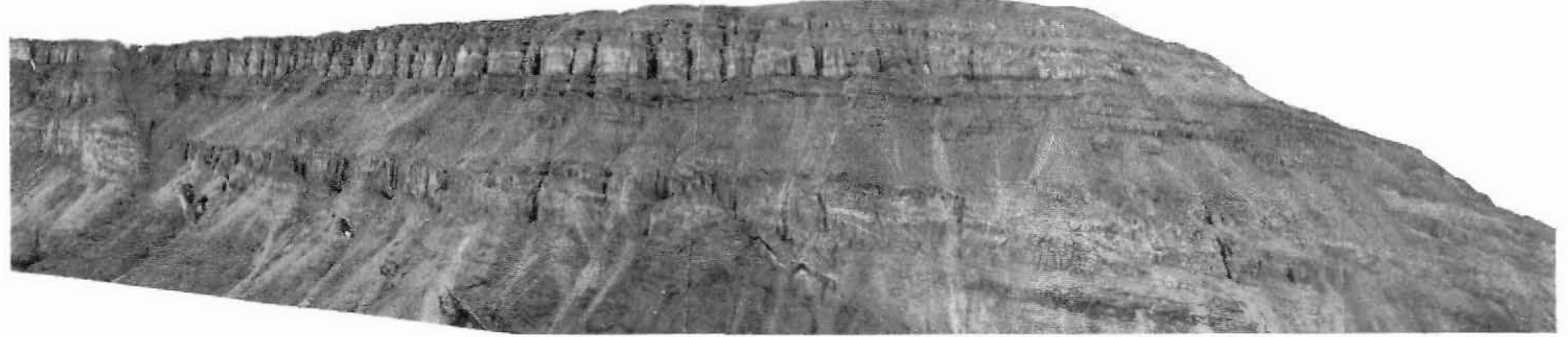

Fig. 5. Prograding clinoform inner shelf slope of the Middle? Cambrian - lowermost Ordovician Perssuaq Gletscher Formation (Tavsens Iskappe Group). The slope has a primary depositional dip of up to $30^{\circ}$. Subhorizontal beds overlying the upper part of the clinoform sequence form part of the Wandel Valley Formation. The slope deposits consist of the alternating sandstones, dolomites and intraformational conglomerates shown on figs 7,8 . Eastern margin of Freuchen Land, on the west side of the glacier flowing into Navarana Fjord. Cliff approximately $400 \mathrm{~m}$ high.

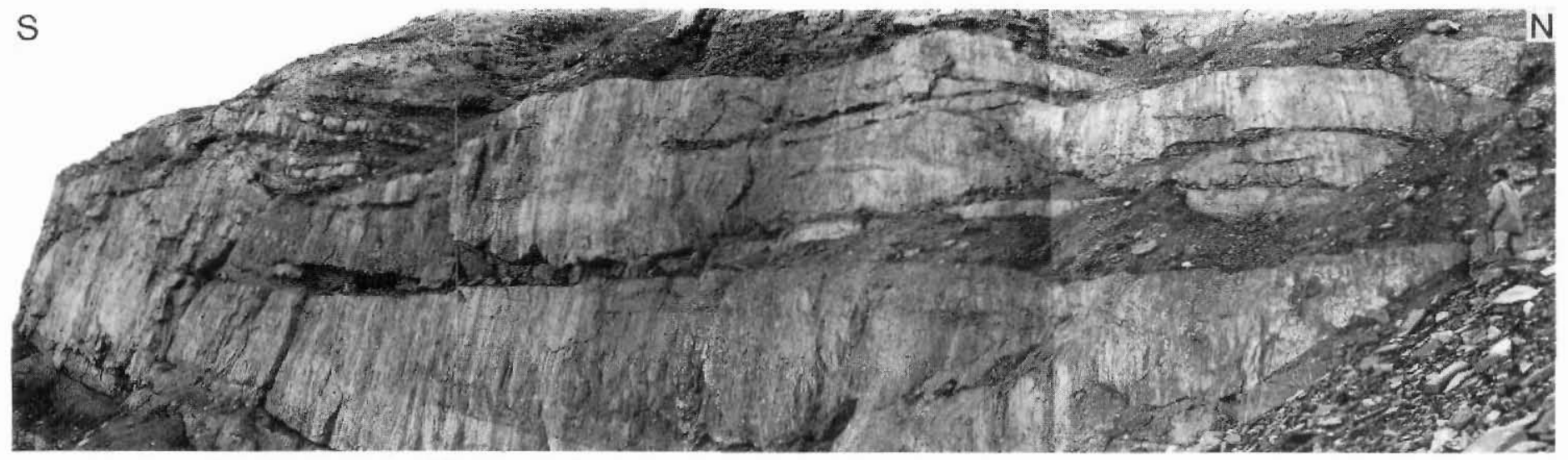

Fig. 6. Upper part of the Navarana Fjord Member showing the complexly amalgamated nature of the carbonate conglomerate. Transport direction from left (south) to right (north). Same locality as fig. 9. Figure to the right indicates scale. 


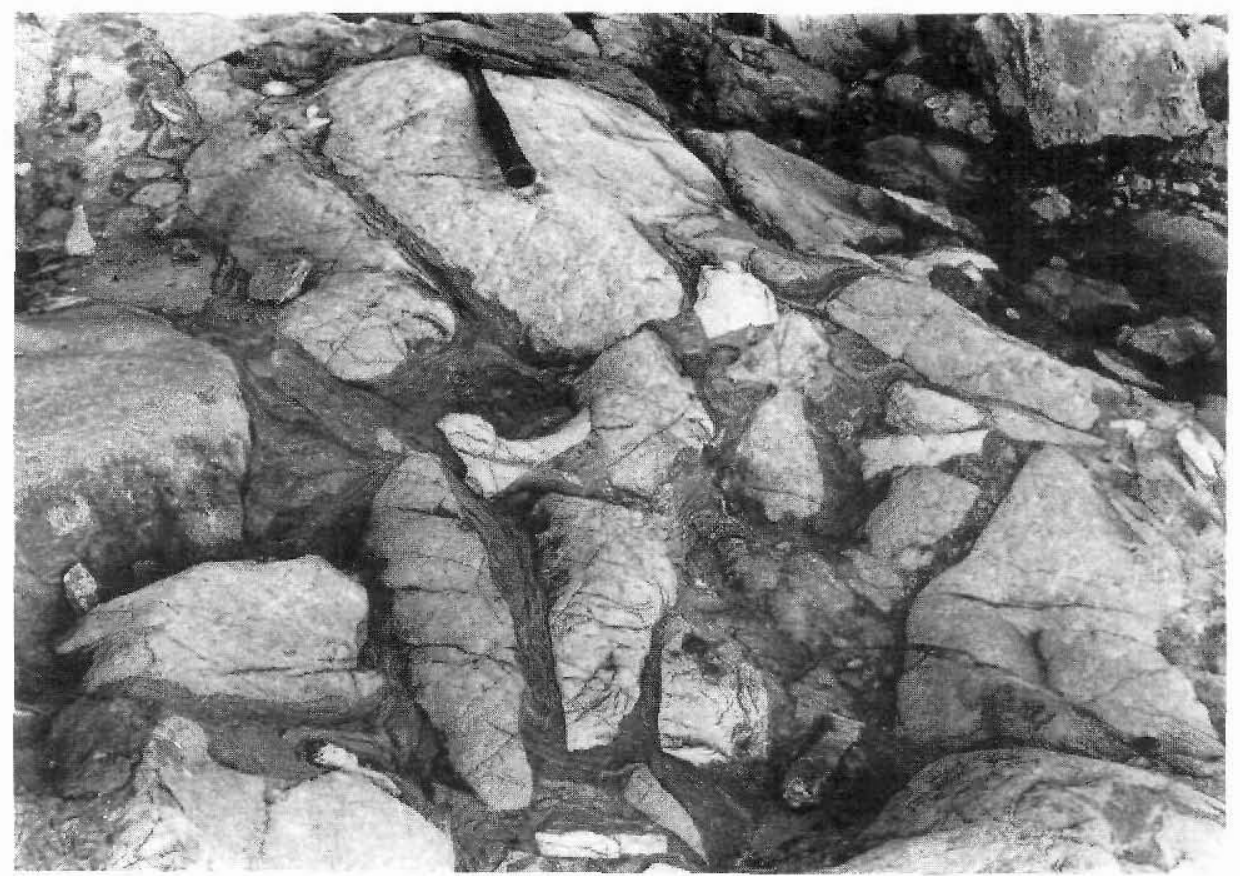

Fig. 8. Intraformational breccia formed by slope collapse and mass flow of poorly consolidated sandstone down the clinoform slope shown in figs 5,7 .

(150-160 $\mathrm{m}$ and $210-230 \mathrm{~m}$ in fig. 7). The latter three facies represent components of major, sigmoidal, clinoform sand bodies, deposited during a single pulse of progradation. Passing up the depositional slope, it is common to observe a lateral transition from thin, parallelbedded, bioturbated sandstone into trough cross-bedded sandstone (fig. 7).

The dolomite units drape the oversteepened clastic 'front' and represent periods of slow sedimentation and low clastic input; clearly clastic progradational events were sufficiently rare to allow carbonate production to resume in the shallow nearshore zone. Much of this clastic detritus was probably trapped in inner shelf regions in some areas since little sandgrade detritus is recognised in the outer shelf-slope sequences of northern Lauge Koch Land and northwest Peary Land (Higgins \& Soper, 1985). In the Johannes V. Jensen Land region much quartz-rich, shelf-derived detritus, however, was deposited in the deep-water trough where it is represented by the Vølvedal Group turbidites (Surlyk \& Hurst, 1984); this probably reflects the eastward increase in uplift of the shelf which, in the eastern Peary Land region, was probably exposed for much of the Middle and Late Cambrian.

\section{The Ordovician-Silurian platform margin}

In middle Ordovician times the margin of the carbonate platform migrated northwards to coincide with the shelf-slope break, and a steep scarp configuration was eventually developed with an abrupt transition to the shales and turbidites of the trough (Hurst \& Surlyk, 1982, 1983; Surlyk \& Hurst, 1984) (figs 9, 10). 
The exact nature of the Ordovician platform margin is not known since it is buried by younger, Silurian deposits. Ordovician platform carbonates, however, can be traced to the location of the exposed Silurian scarp on the west coast of Navarana Fjord (fig. 9). Farther north, Ordovician rocks are again exposed in the Navarana Fjord anticline where they are developed as black basinal mudstones and cherts. The present-day north-south distance between the Navarana Fjord scarp and anticline is $15 \mathrm{~km}$ but the original distance was probably slightly greater; A. K. Higgins (personal communication, 1986) suggests a tectonic shortening between the two features of about $8 \%$, corresponding to an original distance of $16 \mathrm{~km}$. Transitional slope facies located between the Ordovician platform carbonates and contemporaneous trough mudstones and cherts have not been observed in North Greenland. The shortness of the distance suggests a relatively abrupt transition between platform and trough, possibly coinciding with the Navarana Fjord scarp.

The Early Silurian platform-trough boundary is, in contrast, well-known due to excellent exposures in Navarana Fjord and J. P. Koch Fjord. The top of the carbonate scarp, the adjacent trough turbidites of the Merqujôq Formation, the transgressing mudstone of the Thors Fjord Member, and the overlying turbidites of the Lauge Koch Land Formation are exposed in the west coast section in Navarana Fjord (fig. 9). Almost $800 \mathrm{~m}$ of the scarp and the adjacent Merqujôq Formation form the east coast section. The Thors Fjord Member drapes the truncated edge at the top of the scarp but has been removed by modern erosion over the platform (figs 9, 10). The combined evidence from the two sections shows that the edge of the platform during latest Ordovician - Early Silurian times was developed as a steep scarp.

The carbonate platform sequence south of the scarp can be subdivided into a number of subhorizontal lithostratigraphic units which can be traced laterally over large distances without significant changes. When approaching the scarp this stratigraphy breaks down and in the northernmost kilometre the formations can no longer be traced with certainty (J. S. Peel, personal communication, 1986; Sønderholm et al., 1987; and own observations). The carbonates of the scarp region are of shallow subtidal to peritidal origin, but further petrographic studies are necessary to allow more detailed environmental interpretations. The 'amalgamated' stratigraphies and the facies character together suggest that a slightly elevated rim existed along the scarp.

The carbonates of the platform margin dip gently towards the north. The dip increases, however, to about $20^{\circ}$ when approaching the scarp, and intraformational conglomerates appear. The cobble and boulder sized 'clasts' do not seem to be transported. The brecciated beds are rich in brachiopods, gastropods, cephalopods and corals and contain abundant stylolites and spar-filled vugs. All cracks and interstices between 'clasts' are lined with several generations of spar and infilled with carbonate or quartzose turbidite sand.

The increased dip, fracturing and brecciation probably result from gravitational instability in the scarp area during upwards and outwards growth of the platform margin. These processes eased erosion of the scarp rim. The top $300-400 \mathrm{~m}$ of the carbonate sequence thus underwent strong headwards erosion resulting in the formation of the concave-up $30^{\circ}$ dipping platform edge (fig. 9).

The Silurian part of the platform margin carbonate sequence is about $700 \mathrm{~m}$ thick. It corresponds to about $2800 \mathrm{~m}$ of Upper Llandovery trough turbidites of the Merqujôq Formation and at maximum a few tens of metres of Lower - Middle Llandovery shales. The $2800 \mathrm{~m}$ is a maximum figure measured in northern Nyeboe Land by Larsen \& Escher (1985). Estimates of maximum thickness to about $1000 \mathrm{~m}$ in western Peary Land (Hurst \& Surlyk, 
S

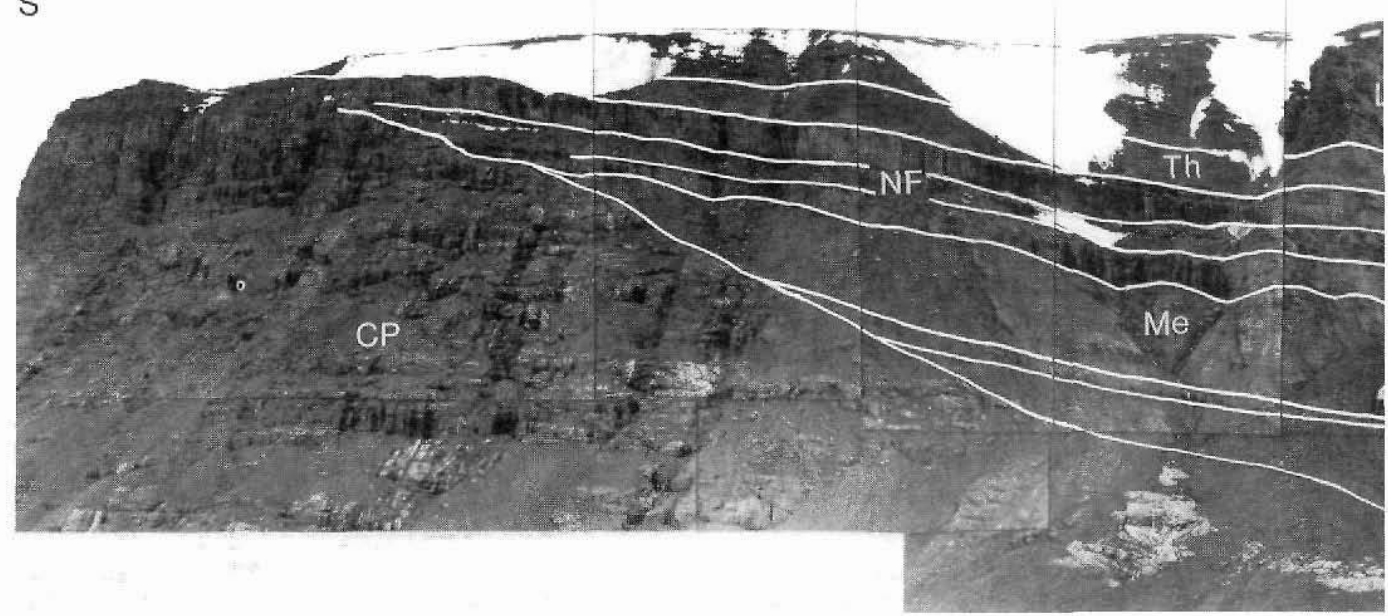

Fig. 9. Gently dipping top part of the Navarana Fjord scarp. CP: the Lower Silurian carbonate platform. Me: Upper Llandovery trough turbidites of the Merqujôq Formation with thin wedge of platform derived conglomerate. NF: amalgamated carbonate conglomerate of the Navarana Fjord Member, type section. Th: black mudstones of the Thors Fjord Member, uppermost Llandovery. LK: turbidites of the

1982) are uncertain. From field evidence the thickness in Navarana Fjord can only be roughly estimated to about $2000 \mathrm{~m}$. The conformable drape of carbonate platform and Merqujôq Formation turbidites by the mudstones of the Thors Fjord Member (fig. 10) shows that when turbidite deposition was initiated the floor of the trough was $(2000-700) \mathrm{m}=$ $1300 \mathrm{~m}$ below the top of the platform. This is correct under the premises that subsidence and sedimentation rates of carbonates and turbidites were uniform in the relatively short time interval of the Late Llandovery. The monotonous nature of the turbidite sequence and to some extent also of the platform margin carbonates suggests that the second premise is roughly fulfilled. Sedimentary loading of the trough with a sequence about three times thicker than that loading the platform, results in a relatively greater subsidence of the trough. The purely tectonic subsidence cannot be evaluated for the trough.

As a first approximation it is, however, considered justified to estimate a maximum water depth in the trough of about $1300 \mathrm{~m}$ at the onset of turbidite deposition. The turbidite sequence is very sand-rich and the effect of differential compaction of carbonates and turbidites is neglected here. Sedimentation of $100 \mathrm{~m}$ of carbonates thus corresponds to roughly $285 \mathrm{~m}$ of turbidites. This means that after deposition of half of the Silurian carbonate sequence the water depth in the trough was still about $650 \mathrm{~m}$. The turbidites only reached the base of the Silurian carbonates when $455 \mathrm{~m}$ of carbonates had been deposited. They were exposed in the scarp forming the platform edge. The lower part of the scarp dips about $45^{\circ}$, while the top $300-400 \mathrm{~m}$ form a seawards-facing concave-upwards surface dipping about $30^{\circ}$ (figs 9,10 ).

The turbidites rapidly filled the trough and are in direct depositional contact with the carbonates of the scarp. Several carbonate conglomerates are interbedded with the turbidites. They are disorganised with poorly sorted clasts in the pebble, cobble and boulder grades, 


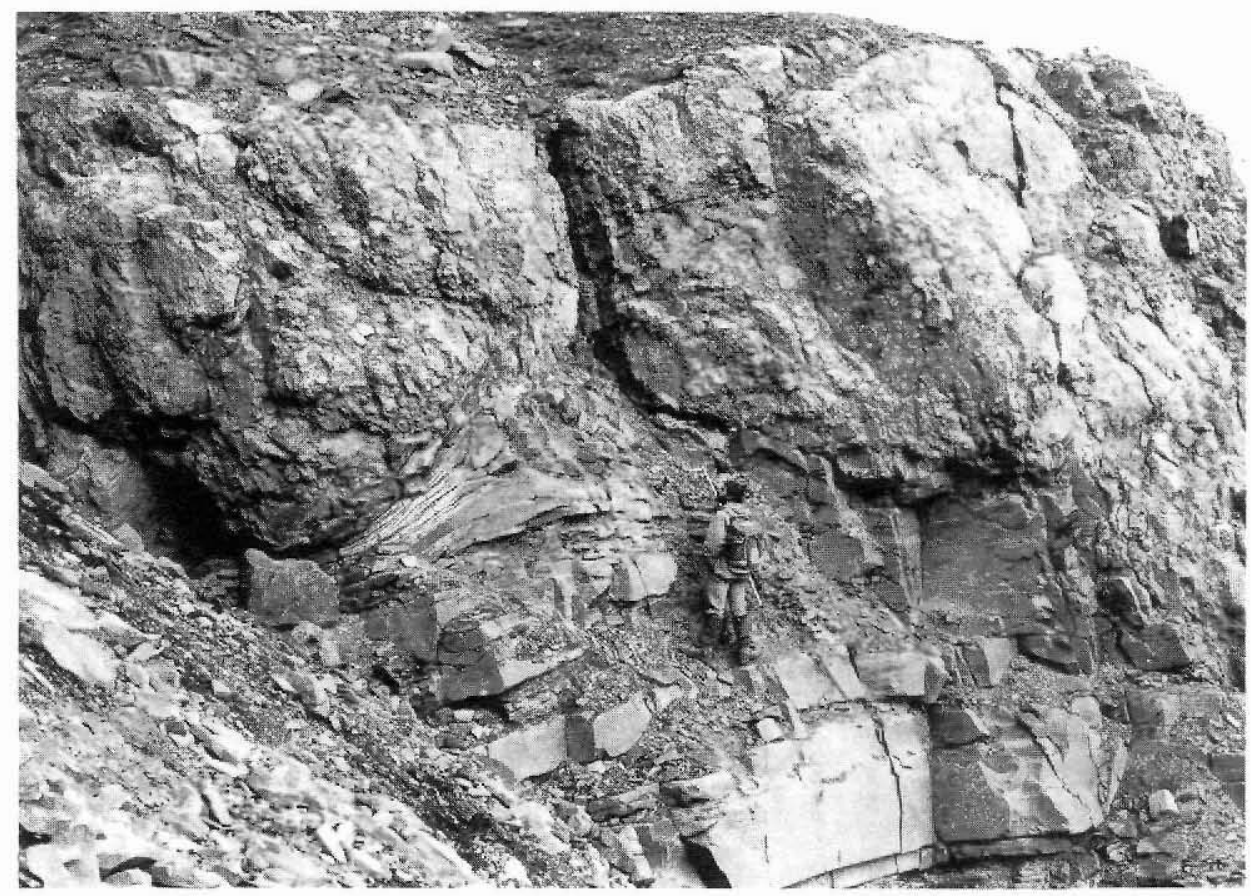

Fig. 11. Platform derived carbonate conglomerate interbedded with Merqujôq Formation turbidites (can be seen as a thin wedge on fig. 9). Note the large-scale load structures of the conglomerate into the underlying sandstone turbidites.

and are commonly deeply loaded down into the underlying turbidites (fig. 11). The conglomerates wedge out towards the north over a few kilometres, and were derived from the fractured platform edge. The turbidites are medium to thick-bedded fine-grained sandstones and flow direction was parallel to the scarp at an average direction of $255^{\circ}$ in Navarana Fjord (fig. 12). Palaeocurrents of the highest Merqujôq Formation turbidites were slightly deflected towards the south with an average palacocurrent direction of $226^{\circ}$ (fig. 12).

The trough eventually filled up with turbidites and the platform foundered and was covered by the black mudstones and thin-bedded turbidites of the Thors Fjord Member (fig. 9).

In the Navarana Fjord section the drowning of the platform was associated with deposition of a series of extensive carbonate conglomerates constituting the Navarana Fjord Member (Surlyk \& Ineson, 1987) (fig. 6). They were derived from a position further south on the platform where the carbonates were not yet covered by mudstones or turbidites.

These conglomerates rest on platform carbonates to the south and on Merqujôq Formation turbidites north of the scarp. They can be traced for at least three kilometres north of the buried scarp until they finally wedge out (fig. 9).

The conglomerates form a thick amalgamated unit with a thin sequence of alternating turbidites and conglomerates in the middle. In detail the conglomerate unit is extremely complex. The individual beds form huge loads down into the underlying turbidites and show marked pinching, swelling and wedging (fig. 6). Deposition was from viscous debris flows on 
Fig. 12. Palaeocurrent roses from the Merqujôq Formation shown in fig. 9. A shows the scarp parallel palaeocurrent direction in the lower part of the turbidite sequence. B shows the southwards deflection in the top part of the turbidite sequence probably caused by the overflow of turbidity currents of the concave-up erosional top part of the scarp seen in figs 9,10 .
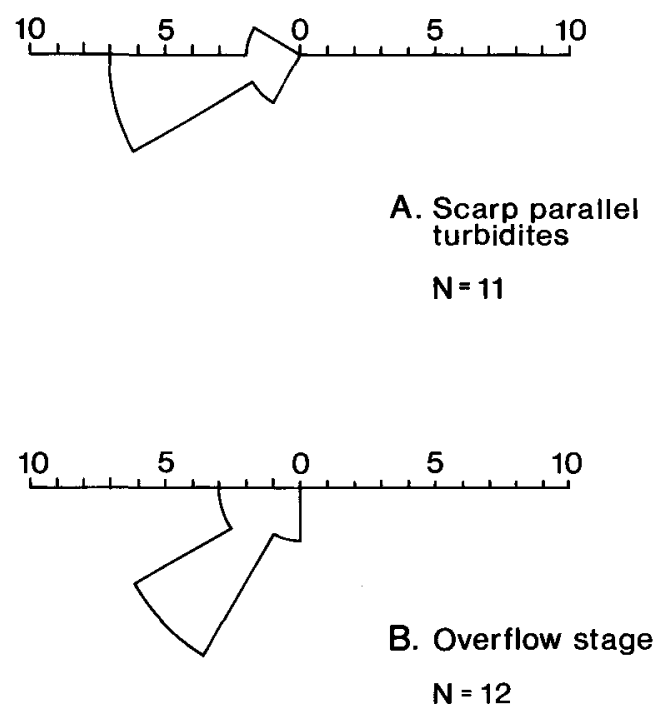

a gentle slope. The conglomerate unit is an important geologic and stratigraphic marker and is recognised as a separate member of the Merqujôq Formation, the Navarana Fjord Member (Surlyk \& Ineson, 1987).

Acknowledgements. We thank A. K. Higgins, J. S. Peel and M. Sønderholm for critically reviewing the manuscript, and B. Larsen, B. Sikker Hansen and J. Lautrup for technical assistance.

\section{References}

Bryant, I. D. \& Smith, M. P. 1985: Lowermost Ordovician sandstones in central North Greenland. Rapp. Grønlands geol. Unders. 126, 25-30.

Dawes, P. R. 1976: Reconnaissance of Eocambrian and Lower Palaeozoic strata in south-western Peary Land, North Greenland. Rapp. Gronlands geol. Unders. 80, 9-14.

Friderichsen, J. D. \& Bengaard, H.-J. 1985: The North Greenland fold belt in eastern Nansen Land. Rapp. Grønlands geol. Unders. 126, 69-78.

Friderichsen, J. D., Higgins, A. K., Hurst, J. M., Pedersen, S. A. S., Soper, N. J. \& Surlyk, F. 1982: Lithostratigraphic framework of the Upper Proterozoic and Lower Palaeozoic deep water clastic deposits of North Greenland. Rapp. Grønlands geol. Unders. 107, 20 pp.

Higgins, A. K. \& Soper, N. J. 1985: Cambrian - Lower Silurian slope and basin stratigraphy between northern Nyeboe Land and western Amundsen Land, North Greenland. Rapp. Grønlands geol. Unders. 126, 79-86.

Hurst, J. M. 1984: Upper Ordovician and Silurian carbonate shelf stratigraphy, facies and evolution, eastern North Greenland. Bull. Grønlands geol. Unders. 148, 73 pp.

Hurst, J. M. \& Peel, J. S. 1979: Late Proterozoic(?) to Silurian stratigraphy of southern Wulff Land, North Greenland. Rapp. Gronlands geol. Unders. 91, 37-56.

Hurst, J. M. \& Surlyk, F. 1980: Notes on the Lower Palaeozoic clastic sediments of Peary Land, North Greenland. Rapp. Grønlands geol. Unders. 99, 73-78. 
Hurst, J. M. \& Surlyk, F. 1982: Stratigraphy of the Silurian turbidite sequence of North Greenland. Bull. Grønlands geol. Unders. 145, 121 pp.

Hurst, J. M. \& Surlyk, F. 1983: Initiation, evolution and destruction of an Early Paleozoic carbonate shelf, eastern North Greenland. J. Geol. 91, 671-691.

Hurst, J. M. \& Surlyk, F. 1984: Tectonic control of Silurian carbonate-shelf margin morphology and facies, North Greenland. Bull. Am. Ass. Petrol. Geol. 68, 1-17.

Hurst, J. M., McKerrow, W. S., Soper, N. J. \& Surlyk, F. 1983: The relationship between Caledonian nappe tectonics and Silurian turbidite deposition in North Greenland. J. geol. Soc. Lond. 140, 123131.

Ineson, J. R. 1985: The stratigraphy and sedimentology of the Brønlund Fjord and Tavsens Iskappe Groups (Cambrian) of Peary Land, eastern North Greenland. Unpubl. Ph.D. thesis, University of Keele, 310 pp.

Ineson, J. R. \& Peel, J. S. 1980: Cambrian stratigraphy in Peary Land, eastern North Greenland. Rapp. Grønlands geol. Unders. 99, 33-42.

Ineson, J. R. \& Peel, J. S. 1987: Cambrian platform - outer shelf relationships in the Nordenskiöld Fjord region, central North Greenland. Rapp. Grønlands geol. Unders. 133, 13-26.

James, N. P. 1983: Reef. In Scholle, P. A., Bebout, D. G. \& Moore, C. H. (edit.) Carbonate depositional environments. Mem. Am. Ass. Petrol. Geol. 33, 345-440.

Larsen, P.-H. \& Escher, J. C. 1985: The Silurian turbidite sequence of the Peary Land Group between Newman Bugt and Victoria Fjord, western North Greenland. Rapp. Grønlands geol. Unders. 126, $47-67$.

O'Connor, B. 1979: The Portfjeld Formation (?early Cambrian) of eastern North Greenland. Rapp. Grønlands geol. Unders. 88, 23-28.

Peel, J. S. \& Wright, S. C. 1985: Cambrian platform stratigraphy in the Warming Land - Freuchen Land region, North Greenland. Rapp. Grønlands geol. Unders. 126, 17-24.

Sønderholm, M., Harland, T. L., Due, P. H., Jørgensen, L. N. \& Peel, J. S. 1987: Lithostratigraphy and depositional history of Upper Ordovician-Silurian shelf carbonates in central and western North Greenland. Rapp. Grønlands geol. Unders. 133, 27-40.

Soper, N. J. \& Higgins, A. K.: A shallow detachment beneath the North Greenland fold belt: implications for sedimentation and tectonics. (Submitted to Geol. Mag.).

Surlyk, F. 1982: Nares Strait and the down-current termination of the Silurian turbidite basin of North Greenland. In Dawes, P. R. \& Kerr, J. W. (edit.) Nares Strait and the drift of Greenland: a conflict in plate tectonics. Meddr Grønland, Geosci. 8, 147-150.

Surlyk, F. \& Hurst, J. M. 1983: Evolution of the early Paleozoic deep-water basin of North Greenland aulacogen or narrow ocean? Geology 11, 77-81.

Surlyk, F. \& Hurst, J. M. 1984: The evolution of the early Paleozoic deep-water basin of North Greenland. Bull. geol. Soc. Am. 95, 131-154.

Surlyk, F. \& Ineson, J. R. 1987: The Navarana Fjord Member (new) - an Upper Llandovery platform derived carbonate conglomerate. Rapp. Grønlands geol. Unders. 133, 59-63.

Surlyk, F., Hurst, J. M. \& Bjerreskov, M. 1980: First age-diagnostic fossils from the central part of the North Greenland foldbelt. Nature, Lond. 286, 800-803.

Surlyk, F., Hurst, J. M. \& Pedersen, S. A. S. in press: Stratigraphy of the Cambrian-Ordovician deepwater sequence of Peary Land, North Greenland. Unpublished manuscript. 